\title{
ЧАС І ПРОСТІР В КУЛЬТУРІ ПЕРЕХОДУ: ВІД ФІЛОСОФІї ЖИТТЯ ДО СИНЕРГЕТИКИ
}

\section{Л.С. Горбунова}

Час є однією з тих реалій, що визначають смислове поле людського світосприйняття. В уявленні про час концентруються простота і ясність буденного світовідчуття і складність, парадоксальність і навіть загадковість його у світорозумінні. Це завжди привертало увагу філософів, які в своїх концептуалізаціях, наближаючись до загадки часу у різних контекстуальних полях, різних філософських і наукових парадигмах, свідчили про чисельні труднощі у вирішенні цього питання, особливо у спробі перейти від буденного уявлення про час до відтворення його або в понятті, або в конституюванні його як категорії, чи в осмисленні як екзистенціалу.

Кожна історична епоха розвитку мислення має певні загальні підходи до розуміння часу, незважаючи на відмінність чисельних концепцій. Уявлення про час і простір завжди являється репрезентативною ознакою тієї чи іншої картини світу, котра, в свою чергу, виступає формою самопізнання культури. Можна сказати, що саме через ці основоположні категорії в науковій і філософській картині світу відбивається самопізнання культури в її історичній динаміці.

В цьому твердженні ми спираємося насамперед на так звану «сильну програму» британського філософа і соціолога науки Девіда Блура, яка пояснює будь-яке знання (як соціо-гуманітарне, так і природничо-наукове) як спричинене соціально-культурними умовами [14].

Цю думку поділяє і Зигмунт Бауман, зазначаючи, що поняття простору «усередині» та «зовні» являлись по суті лише концептуальними похідними від часових та вартісних обмежень свободи пересування людини. Поняття «відстані» - це не лише об'єктивна фізична даність, а й соціальний продукт; її довжина залежить від швидкості, з якою ми її долаємо [1]. Ідеї «соціального простору» i «культурного простору» виникають не шляхом метафоричної транспозиції понять фізичної науки, пов'язаних 3

Актуальні проблеми духовності

(Відп. ред.: Я.В. Шорамко)

Кривий Ріг (2005), 164-176 
«об'єктивним» простором, а якраз навпаки: той простір і відстань, які ми сьогодні називаємо «об'єктивними», спочатку вимірювалися в критеріях, пов'язаних з людським тілом і людськими відносинами. Людське тіло в самому буквальному сенсі, абсолютно не пов'язаному з філософією, за давніх-давен виступало як «міра всіх речей». 3 введенням стандартних і обов'язкових одиниць виміру параметрів простору (відстані, поверхні, об'єму) його соціокультурна причинність не зменшилась, а скоріше навпаки, посилилась, оскільки збільшення фізичного простору свідчить про розширення та ускладнення простору буття людської культури в його цілісності і внутрішній взаємообумовленості.

Особливо цікавим є процес експлікації структур соціокультурного буття в понятті часу, коли сам час як спосіб буття у світі постає як напружений екзистенціал, як смислопороджуюча структура по відношенню до пізнання та розуміння. Це характерно, насамперед, для культурних епох, які можна розглядати у якості перехідних.

Осмислюючи соціокультурні трансформації кінця XIX - початку XXI століття, ми приходимо до розуміння цієї епохи у розвитку культури як перехідної. Про це свідчить насамперед розпад універсальної картини світу, на засадах якої вибудовувалася західна культура епохи модерну, або культура Нового часу, та переоцінка систем інтерпретації історичного часу та простору в науці і філософії. Сам факт радикальних змін у відносинах з часом $є$ однією із значущих прикмет перехідності в культурі.

В кінці XIX - на початку XX століття, коли західна культура, культура модерну, вичерпуючи свій еволюційний потенціал вступає у фазу переходу, становлення одержує пріоритет по відношенню до ставшого буття. Принцип «часовості» одержує цілковиту автономію в тих філософських напрямах, де провідним стає поняття життя - в неогегельянстві, віталізмі, в філософії життя, в різних варіантах еволюціонізму, елімінуючи надчасову основу життя, і в цій послідовності відривається від простору і навіть протиставляється йому. Головними характеристиками часу стають відносність і незворотність.

На наш погляд, найбільш яскравими інтерпретаціями часу, що мали вирішальне значення для розвитку наукової і філософської думки в XX столітті, були концепції, запропоновані представниками «філософiї життя»: Ф.Ніцше, В. Дільтей, А.Бергсон, Г. Зіммель, О. Шпенглер. В певній спорідненості до їх поглядів знаходяться концепції М.Шелера, Г. Кайзерлінга, Х. Ортега-і-Гассета, Вяч. Іванова та ін.

Вслід за своїми попередниками, німецькими романтиками, «філософи життя» піддають критиці механістичний світогляд у всіх його проявах насамперед в науці і породженій ним технічній цивілізації. Для представників класичної науки, представленої експериментально-математичним природознавством, час виступав як свого роду «вмістилище» для сплива- 
ння процесів, байдуже до їх змісту. Ще за часів Галілея у механіці було встановлено закон, що пов'язував між собою простір і час, і таким чином був створений математичний апарат для вимірювання руху. Це привело до «геометричного» тлумачення поняття часу та зображення його у вигляді прямої лінії, що безкінечно тягнеться в обох напрямах. Внаслідок цього фізика абстрагувалася від численних характеристик часу, котрі їй заважали у вирішенні питання вимірювання руху, і насамперед від його незворотності. В механіці час інституювався тільки як принцип неперервного рівномірного змінювання, зворотного за своєю природою. Таке розуміння було обумовлене не лише логікою розвитку самої науки, але й «металогікою» розгортання (точніше, своєрідним історичним гештальтом) «проекту модерну» в культурі Нового часу. Тобто, йдеться про наявність метаструктури історичного циклу європейської культури, що виводила філософію на есенціалісько-універсалізуючий рівень рефлексії, який втягував в себе і нівелював мікрорівень сприйняття часу-рівень екзистенції атомарного індивіду, що завжди існує як спонтанне виникання i поновлення, або вічне становлення, самовідчуття певного буття.

Механістично-розсудливе, «геометричне», чисто кількісне розуміння часу стало основним об'єктом критики з боку філософії життя. Ця філософія покликана новітнім часом історії європейської культури як передчуття кризи і самовичерпання, «заходу Європи», а саме - завершення одного циклу історичного розвитку і початку епохи переходу до іншого. На противагу есенціаліським спекулятивним метатеоріям вона визначає реальність як життя, «життєвий порив», «живий дух», що з самого початку формує уявлення про час як форму здійснювання, справджування життя. В залежності від того, як саме трактується життя окремими представниками цієї філософії-як «живий організм» (біологічно), як «потік переживань» (психологічно), як «живий дух» (культурно-історично), як «життєвий порив» (метафізично), можна розрізнити декілька тенденцій усередині цього напряму, а саме: біологічну (Ф.Ніцше), психологічно-натурфілософську (А.Бергсон) і трансценденталісько-історициську (В. Дільтей).

Зв'язок життя і часу у Нішше достатньо зовнішній: сутність життя завжди однакова, а оскільки життя - це дійсна основа буття, то буття $\epsilon$ щось завжди саме собі рівне, що незмінно повертається саме до себе, буття $€$ «вічне повернення». Дійсно глибокий зв'язок між життям і часом встановлюють Бергсон та Дільтей, чиї концепції стоять біля витоків сучасних наукових и філософських трактувань часу.

Значний вплив на творчість Бергсона мала теорія еволюціонізму Спенсера. Оскільки еволюційний процес відбувається в певному часі, Бергсон дійшов висновку, що геометрична модель часу є обмеженою. В механіці використовується уявлення про час як специфічну і багато в чому обмеже- 
ну сутність. Кожний момент часу є зовнішнім у відношенні до іншого моменту, тому вони рівнозначні. Геометрична модель часу, просторовість це характеристика речей. Свідомість, натомість, характеризує тривалість.

Отже, за Бергсоном, час - це не зовнішня характеристика життя, індиферентна до його змісту форма плинності, а найбільш суттєве визначення його змісту. Життя, рух, творчий розвиток, як вважає Бергсон, незбагненні з боку наукового інтелекту, тому що інтелект не в змозі осягнути неперервність часу, цілісність часової структури. Лише інтуїція, що споріднена з цією структурою і являє собою «бачення життя самим життям», або самоспоглядання життя, здатна адекватно сприйняти цю плинну, неподільну стихію вічного становлення. Бергсон протиставляє час реальний - тривалість (життя душі) - часу умовному, що конструюється наукою і буденним мисленням з практичною метою- метою вимірювання. Критерієм реальності часу він вважає його безпосередню даність у феномені свідомості, його «переживання» [2]. Свідомість має здатність безпосередньо вловити незавершену плинність часу. Тривалість означає, що ми живемо сучасним зі спогадами про минуле і в передбаченні майбутнього. Поза свідомістю минулого немає, а майбутнє не настане. Свідомість скріплює минуле і майбутнє сучасним. Кількісна нерозрізненість моментів не притаманна свідомості, для якої одна мить може тривати вічно. В протяжному потоці свідомості між різними моментами часу відбувається взаємопроникнення, вони можуть нанизуватися і зміцнювати один одного. Конкретний час - це життєвий потік з елементами новизни у кожній миті. Бергсон порівнює цей час з клубком, котрий, збільшуючись, не втрачає накопичене. А механічний час можна порівняти з намистом, в якому кожний момент часу існує сам по собі. Така модель часу може бути ефективною в рамках практичних задач науки, але очевидна іiї неадекватність у справі дослідження свідомості та різних її проявів.

За своєю природою час є синтетичним об'єктом. «Синтетизм» часу проявляється у тому, що він складається із різновидних частин: модус сучасного розташовано у полі іманентності, тобто людина схоплює сучасне в потоці безперервно змінюючих один одного «тепер». Що ж стосується модусів минулого і майбутнього, то вони можуть існувати тільки у вигляді уявлень і розташовані у полі трансценденції. Таке виокремлення різних когнітивних полів при вивченні якостей часу може бути корисним в дослідженнях процесів становлення в області духовної реальності.

Ідея якості часу пов'язана з ідеєю множинності часів. У Парижі в 1922 році на засіданні Філософського товариства Бергсон відстоював ідею співіснування численності «живих» часів. Але Ейнштейн, як відомо, категорично заперечував таке розуміння часу. I хоч судження Бергсона не вписувались в традиційні уявлення, але виявилось, що саме ці незвичні, з точки зору його сучасників, погляди багато в чому близькі ідеям, що виті- 
кають $з$ парадигми нелінійності. Бергсонівський «живий» час, або тривалість, відноситься до фундаментальних, невід'ємних якостей становлення і незворотності [5].

Сьогодні ці нові уявлення щодо типів зв'язку простору і часу складаються в царині постнекласичної науки, зокрема синергетики. В постнекласичних дослідницьких контекстах увага приділяється насамперед аналізу складних систем, що самоорганізуються. Для опису процесів самоорганізації використовуються нелінійні математичні моделі. В процесі дослідження розвитку нестаціонарних і відкритих дисипативних структур неможливо обмежитися уявленням про час як про чисто кількісну характеристику процесів. В зазначених системах мають місце стадії нестійкості, режими із загостреннями, в ході яких відбуваються якісні зміни. Через це в синергетиці враховується не тільки вплив більш ранніх стадій на наступні, минулого на сучасне, але й майбутнього на сучасне. Саме про це писав Бергсон в одному із своїх листів: «Уявлення про множинність ,взаємопроникнення" повністю відмінні від нумеричної множинності - уявлення про тривалість гетерогенні, якісні, творчі, - ось пункт, з якого я вийшов і до якого весь час повертаюсь» [3].

Думка Бергсона про необхідність характеризувати час не тільки кількісно, але й якісно, дуже близька моделям тих просторових і часових відносин в структурах, що самоорганізуються, котрі досліджуються синергетикою. Тому його теорію «творчої еволюції» 3 повним правом можна назвати одним із джерел сучасних, постнекласичних наукових ідей [6].

Бергсон послідовно доводив, що філософія може зробити свій внесок у вирішення проблеми часу. Він показав необхідність співвіднесення поняття часу з іншими філософськими категоріями, необхідність пошуку «правильного» місця цієї категорії серед інших. Один із можливих варіантів - це співвіднесення змісту понять «час» i «простір», що утворює нове поняття - «просторовий час».

Метод, за яким зрозуміти річ означає включити їі до системи інших речей, дійсно виправданий. При цьому Бергсон співставляє підходи філософські і природничонаукові. Він зазначає, що природознавці в цілому ряді випадків прагнуть синтезу, конструюють його. А філософія - це вже єдність, вона виходить із єдності, це її органічна риса, її підгрунтя. Що ж стосується бергсонівського поняття «просторового часу», то слід зазначити, що воно має величезний евристичний і прогностичний потенціал для сучасної науки і філософіï.

На відміну від Бергсона, Дільтей вважає, що час - реальність не просто психічна, а скоріше історична. Час виступає як квазісубстанція культурно-історичної реальності. Свій вихідний принцип розуміння життя із нього самого Дільтей протиставляє принципам природничо-наукового мислення, щодо якого поділяє кантіанське розуміння наукового знання як 
знання опосередкованого. На відміну від останнього, життя пізнається як безпосередня цілісність, дана людині у внутрішньому досвіді. Визначення життя як «реальності внутрішнього досвіду» зближує Дільтея 3 Бергсоном, привносячи в його концепцію елемент психологізму. Однак дільтеєвський хід мислення має інший напрям, ніж той, що ми бачили у Бергсона. Відповідно Дільтей розробляє і нову концепцію часу, що визначається ним як конкретна, якісно наповнена форма плину життя.

Якщо для Бергсона важливим було підкреслити цілісність структури часу, неможливість поділення тривалості на окремі моменти, то для Дільтея важливішим за все було відмітити єдність, зрощення часу зі змістом, що заповнює його, оскільки час має різний характер в залежності від того, який зміст його наповнює. Коли ми оглядаємося на минуле, пише Дільтей, ми поводимо себе пасивно, бо минуле не можна змінити. Коли ми звертаємося до майбутнього, ми виявляємо себе активними і вільними. Тут поряд з категорією дійсності, що відкривається нам у сучасному, виникає категорія можливості. Ми відчуваємо себе володарями безкінечних можливостей. Таким чином, переживання часу у всіх його напрямах визначає зміст нашого життя. 3 останнього видно, що визначення часу як якісної реальності має сенс тільки по відношенню до людини, оскільки вона діє, ставлячи перед собою цілі і реалізуючи їх, тобто по відношенню до людини історичної, людини - творця культури [7]. Якщо Бергсон фіксує увагу на психічному бутті індивіда, то матеріалом для Дільтея виявляється його культурно-історичне буття. Останнє, за Дільтеєм, повинні досліджувати науки про дух, теоретичним фундаментом для яких має стати нове розуміння часу, бо колишнє не дає можливості проникнути в історичну реальність. Він зазначає, що вчення про просту ідеальність часу не має взагалі ніякого сенсу в науках про дух. Тоді як для природознавства XVII-XIX століть час слугував зовнішньою формою плину явищ, внутрішньо з самим часом не пов'язаних (саме цей принцип був прийнятий Кантом в його вченні про час як апріорну форму внутрішнього відчуття), для Дільтея, який вважав час субстанцією самого життя, цей принцип неприйнятний. За допомогою тих засобів, якими користується наука, пізнаючи природу, духовний зв'язок, як вважає Дільтей, не може бути схоплений саме тому, що в його основі лежить «непрозірна для мислення» єдність часу, що переживається.

Цю переконливість Дільтея в нездатності наукового мислення (мається на увазі класична наука) осягнути сутність «конкретного» часу і сформувати судження про життєву реальність поділяє 3 ним більшість представників філософії життя, але в питанні, яким чином це можливо зробити, вони радикально розходяться. Якщо Бергсон впевнений, що «тривалість» споглядається в інтуїції, то Дільтей вважає, що ніяка інтроспекція не в змозі осягнути сутність життя. Якщо Бергсон вважає можли- 
вим пережити тривалість і тим самим інтуїтивно осягнути її, то Дільтей зазначає, що сутність життя невловима в безпосередньому переживанні.

Для Бергсона плин часу - це об'єктивний процес, що хоч і проходить через людську свідомість, але не залежить від неї. Час плине, за Бергсоном, усередині нас, але не завдяки нам. В розумінні Дільтея один із вимірів часу - майбутнє - може існувати лише для людини, яка володіє не тільки пам'яттю (як це було у Бергсона), але й діє відповідно очікуванням, бажанням, сподіванням, меті. Тому час для Дільтея плине не тільки об'єктивно усередині нас, але й завдяки нам. Це специфічно людський час, характеристики якого обумовлені специфічно людським способом життя, який Дільтей називає історією, або культурою. 3 цієї точки зору неможливо розглядати свідомість як те, усередині чого потоком плинуть переживання. Навпаки, свідомість сама активно бере участь у створенні цього потоку. А споглядати себе людина може не безпосередньо, а тільки шляхом споглядання іншого. Внутрішній досвід не може дати достатніх можливостей усвідомити власну індивідуальність. Тільки в порівнянні себе самої з іншими людина здобуває досвід відносно індивідуального в собі, усвідомлюючи насамперед те, що відрізняє її від іншого. Ця думка Дільтея здобула найбільшого розвитку в екзистенціальній філософії.

Досвід відносно індивідуального в собі дає також і освоєння упредметнених форм людської діяльності, в яких знайшли своє втілення індивідуальності як окремих історичних особистостей, так і цілих народів та культур. Таким чином, осягнути життєву реальність, якщо вона вислизає і від природничо-наукового опосередкованого пізнання, і від безпосередньої інтуїщії, можна лише за допомогою третього методу, який розробляв Дільтей - методу розуміння, або герменевтики. Саме цей метод, за Дільтеєм, має допомогти сучасній людині здобути у якості сучасного все минуле людства. Він зазначав, що людина пізнає себе тільки в історії, а не через інтроспекцію.

Із історії він вилучає все субстанціальне, оскільки усяке субстанціальне начало, на думку Дільтея, є чимось поза історичним. Єдиним субстратом історії проголошується «часовість», плинність («временность»). Тут виникає небезпека релятивізму, якого не вдалося уникнути Дільтею. Але здійснена ним спроба розглядати час як реальність історичну і пов'язана 3 нею інтерпретація часу як структури, що містить в собі три моменти: минуле, сучасне і майбутнє, яку не можна розглядати у відриві від змісту - це великий здобуток мисленнєвого досвіду, який знайшов свій подальший розвиток в екзистенціальній філософії та герменевтиці.

Радикальній критиці математизацію світу, що відбувалася у фізиці Нового часу, піддав і засновник феноменології Е. Гуссерль, протиставляючи цьому свій метод як безпосереднє споглядання феноменів такими, якими вони самі себе показують. В «Кризі європейських наук» він за- 
значає, що в результаті застосування нової математики природознавство робить великі успіхи, але це відбувається за рахунок втрати ним зв'язку з гуманістичною складовою життя, що призводить до його «технізації». Він бачить спасіння від техніцизму та натуралістичного об'єктивізму науки в поновленні втраченого зв'язку науки із суб'єктом, який здійснює пізнавальну діяльність. Для цього він вводить поняття «життєвого світу», яке постає смисловим підгрунтям всякого людського знання, зокрема поняття часу. «Життєвий світ»- це безпосередня, дорефлективна даність, що передує всім штучним теоретичним поняттям і установкам. Він $є$ світом суб'єкту, а тому має телеологічну структуру, оскільки тісно пов'язаний з цілепокладальною діяльністю людини. Час для людини виступає як феноменально наповнений час «життєвого світу», в якому вона живе і діє як історична істота. Можна сказати, що в «Кризі європейських наук» завдяки введенню поняття життєвого світу Гуссерль перетворює свою трансцендентальну феноменологію на своєрідну філософію історії, вочевидь зближуючись в усвідомленні поняття часу з історичним варіантом філософії життя.

Думку Дільтея і Гуссерля продовжив М. Хайдеггер, подолавший традиційне розуміння часу як «обрію, безкінечного в обидва боки», підкресливши, що головною характеристикою справжньої часовості є її скінченність. Відкрите по відношенню до своєї конечності, людське існування тим самим відкрите буттю: завдяки спрямованості до смерті воно виходить за свої межі, екзистує, чим і визначається незворотність часу: справжній час «часує» («временит») із майбутнього, на відміну від «вульгарного», фізичного часу, вихідний модус якого-«тепер». Саме буття і $\epsilon$ час [13]. Тимчасовість, або скінченність, людського існування, існування соціокультурної цілісності як світу-простору людського буття, є основою його історичності, в якій має свій базис емпірична історія.

Цей «живий» філософський поштовх відчула на собі насамперед гуманітарна наука. Так, переосмислення проблематики часу і простору відбувається в межах теоретичної історії. В 1958 році Фернан Бродель опублікував славнозвісне есе «Історія і соціальні науки...»[4], в якому він стверджував, що час є соціальний витвір. Він виокремив три основні категорії соціального часу, які визначив подвійно: за тривалістю часового інтервалу та за об'єктом виміру (якість часу). В термінах тривалості часового інтервалу він називав свої часи короткостроковим - «історія подій», «епізодична історія»; середньостроковим - кон'юнктурна історія, циклічна історія; довгостроковим - структурна історія. Бродель фактично додав ще й четвертий час - вельми довгостроковий, або надто довгостроковий, і сказав про нього, що «якщо він існує, то він може бути тільки часом мудріїв». Об'єктом виміру являються довгострокові структури (насамперед економічні і соціальні), котрі обумовлюють протягом довгострокового 
часу нашу колективну поведінку - нашу соціальну екологію, наші цивілізаційні зразки і стандарти (патерни), наші способи виробництва, а також циклічні ритми функціонування даних структур - розширення та стиснення економіки, чергування певних політичних і культурних явищ, котрі відбуваються регулярно.

Думку про якісну множинність часів розвиває I. Валлерстайн, коли він стверджує, що кожному різновиду соціального часу відповідає різновид соціального простору. Отже, можна говорити про соціальні часи-простори. Історична реальність виступає як реальність тривалих, але конечних збірних структур (історичних систем), що мають свої структуровані способи дії (циклічні ритми), але також підвладних безперервним процесам трансформації, які Валлерстайн називає столітніми трендами [8]. Валлерстайн, розглядаючи чотири броделевські часи - епізодичний час, циклічний час, структурний час і час мудріїв, стверджує, що кожен із цих часів має свій простір, i ïх можна поєднати однією категорією «час-простір». Для визначення простору він звертається до тих сутнісних об'єктів, які описуються цим часом, і таким чином знаходить просторові аналоги категоріям соціального часу.

Мисленєві інтенції Валлерстайна ізоморфні також синергетичним уявленням про час-простір існування складних структур як упорядкованих процесів самоорганізації в нелінійному середовищі, що включають біфуркаційну фазу як фазу переходу. Це особливий різновид часу-простору, що характеризується начебто стисненням і руйнуванням структурного (історичного) часу, посиленням нелінійності, і внаслідок цього квантуванням, або індивідуалізацією часу, тобто коли безособистісний, або надособистісний, закон історичної необхідності поступається місцем свободі індивідуального вибору.

Перехід від однієї визначеності до іншої, одного стану в інший, коли система втрачає риси цілісності, які можна ухопити і зафіксувати в поняттях, є особливо важким в динаміці осмислення і смислоутворення. Для цієї стадії характерні процеси деструктивности і хаотизації, які можна охарактеризувати як лімінальні. В цьому питанні актуальними і змістовними можуть бути результати і висновки дослідження в межах культурної антропології, яких дійшли Арнольд ван Геннеп [9] и Віктор Тернер [16]. Досліджуючи лімінальну фазу ритуалів переходу, тобто ритуалів змінення статусу (вікового, соціального, сімейного і т.ін.), в традиційних суспільствах, вони дійшли висновку щодо чіткої структурованості фази переходу, що включає в себе три стадії:

1. відокремлення - вибір та ізоляція індивіда від певної соціальної цілісності, позбавлення індивіда статусних характеристик приналежності до цієї цілісності; 
2. власне перехід - період певного перехідного стану, або лімінальності;

3. реагрегація - відтворення нової цілісності.

В концепції російського формалізму ми знаходимо аналогічні три стадії, а саме: (1) зробити звичне незвичним, дивним - одивовування, або очуднення («остранение»); (2) гра з очудненими смислами; (3) конструювання нового смислового комплексу.

Ще одним аналогічним описом структури переходу є ідея деконструкції Ж. Дерріда, яка трактується як рух мисленєвого досвіду, відкритого абсолютному майбутньому, досвіду невизначеного, невиразного, що явлений в очікуванні іншого і відданий очікуванню іншого і події («событию»). Деконструкція у даному контексті виступає навчанням відкритості майбутньому. Як техніка інтелектуальної роботи з бінарними опозиціями деконструкція передбачає наступні кроки: (1) розбір опозиції; (2) рівняння іiі членів; (3) розглядання на гранично віддаленому рівні дистанціюванні 3 метою виявлення її неможливостей (або нових можливостей) [15].

Як вважає Г.Л.Тульчинський, у всіх цих випадках мова йде про один і той же інваріант стадій в розвитку соціальних, семіотичних і інтелектуальних систем, ключовим моментом в якому $\epsilon$ лімінальна стадія як процес переходу соціально-культурної цілісності (особистості, групи, суспільства) в новий культуральний стан [10, с. 69]. Лімінальність характеризує зміну соціального статусу, цінностей і норм, ідентичності і самосвідомості, осмислення і розуміння, свідомості і мовної практики. Феномен лімінальності є особливо цікавим стосовно до осмислення процесів, які розгортаються в суспільстві, що трансформується, здійснює культурний або цивілізаційний перехід, коли глибокі і радикальні зміни торкаються практично усіх сфер життя: від економічних, політичних і адміністративних реформ до цінностей, норм, способів світобачення і світоставлення в цілому. Сама соціокультурна цілісність суспільства, що трансформується, постає у якості контексту суцільної лімінальності як для індивіда, так і для всякої спільноти як соціокультурної підсистеми.

Структурний час в лімінальному просторі культури, що трансформується, ніби зникає, розпадаючись на індивідуалізовані і підсистемні часи кванти, в хаотизованій динаміці яких спонтанно формуються можливі варіанти нових структурних утворень. Відомо, що в нелінійному класичному середовищі діють квантові правила. Квантовість виявляється притаманною не тільки мікросвітові, але й певному класу нелінійних макросистем, у тому числі і соціокультурних. Блукання у полі можливих шляхів майбутнього розвитку відбувається в просторі потенційної цілісності, про яку можна сказати, що вона структурно позачасова, оскільки містить 
в собі одночасно своє минуле, сучасне і майбутнє. Вона актуалізується насамперед на рівні атомарного індивіду як час-простір індивідуального вибору, що виступає як спонтанна флуктуація, або складова когерентного руху. Осмислюючи потенціальну цілісність із середини лімінального «безчасся», ми ніби линемо над обрієм буття, екзистуючи, намагаючись вловити взаємозв'язок минулого, сучасного і майбутнього як «тривалості» (за Бергсоном), наповненої особистісними почуттями.

Цікавим є те, як показують дослідження нелінійності фізиків і математиків, що не тільки в мисленнєвому процесі можна вловити взаємозв'язок модусів минулого, сучасного і майбутнього. Так, наприклад, такий процес як горіння $€$ по суті «комплексне зображення» усіх стадій процесу в сенсі «одночасного» існування минулого, сучасного і майбутнього. Один із авторів робіт, виконаних в руслі цієї концепції, академік С.П. Курдюмов сказав: «будущее временит настоящее». «Часує» («временит») у сенсі визначає, формує, прогнозує. По суті йдеться про те, що не тільки у нашій свідомості ми можемо помислити «одночасно і про минуле, і про сучасне, і про майбутнє, але і в реальному, об'єктивному процесі, такому, наприклад, як горіння, «співіснують» минуле, сучасне і майбутнє» [6].

Більш того, в останні роки досліджуються «специфічні риси потенційного існування, що являє собою форму цілісності, в якій відсутні виокремленні об'єкти і взаємодії між ними, їх просторово-часові характеристики. Поява просторово-часових і причинних зв'язків стає можливим в результаті порушення вихідної (початкової) симетрії i «обміну сталості» в потенційній структурі» [12, с. 12].

«Нове» відкриття роздільності буття на дві реальності: актуальну, для характеристики якої можна використовувати уявлення про час як час існування структури, і потенційну, при характеристиці якої втрачається сенс уявлень про частину і ціле, про час і простір, обумовлює необхідність переходу до нового погляду на світ, в тому числі на світ людського буття, що є свідченням самого перехідного процесу в культурі. Перехід до нової визначеності структури відбувається у просторі її потенційної реальності як когерентний рух численності атомізованих індивідуальних виборів, якісно наповнених і екзистенційно напружених.

Саме таким і є останній різновид часу-простору, що вводить Валлерстайн. Це час, який Пауль Тілліх називає «kairos», або «якісний» час на противагу «формальному», «кількісному» часу [10]. Саме його Тілліх називає «правильним часом» і «правильним місцем», до якого відноситься концепція кайросу, що розкриває сенс цього часу-простору як фундаментального людського морального вибору. Саме в цьому часі-просторі, говорячи мовою Пригожина, «каскад біфуркацій» забезпечує «перехід до хаосу», а від хаосу - до важко передбачуваного порядоку.

Постнекласична наука, зокрема синергетика як найбільш яскравий iiı 
прояв, у цьому контексті самопізнання культури переходу епохи глобалізації виступає як створений нею соціально і культурно навантажений феномен, що інституювався в області «чистої раціональності» як наукова редукція складних лімінальних станів та трансформаційних процесів, які протікають у соціумі. Актуальним і значущим постає процес експлікації даного смислового коду та його ціннісного потенціалу в гуманітарних науках шляхом філософської рефлексії як «повернення» культурі знання про саму себе. Такі інтенції філософії і методології науки виявляються конгруентними імпліцитним мисленнєвим кодам у різних сферах та модусах культури, прояв яких з часом стає все більш інтенсивним. У цілому в культурі можна спостерігати явище синхронії (за Юнгом) в становленні нової раціональності на засадах універсального інваріанту мислення, характерного саме для фази переходу.

Системоутворюючими параметрами для такого інваріанту виступають категорії часу і простору в новій конфігурації їх співвідношення: провідна роль категорії часу, підпорядкована їй категорія простору. Останнє пояснюється природою самого переходу від однієї історичної структури простору (якої вже немає), до нової (якої ще немає), через процес ліміналізації соціокультурного буття, для якого характерне квантування часу, його зростаюче екзистенціювання в реальному процесі життя людини, «життєвому світі», та екзистенціалізація і феноменологізація в теоретичному осмисленні.

Синергетика як постнекласична наука, так само як і філософія життя на початку перехідної епохи, народжена часом переходу в культурі і покликана ним реалізувати свій ціннісний потенціал у процесуальності фундаментального вибору. Але це можливо лише за умови провідної ролі у реалізації цього потенціалу філософської рефлексії, здатної синтетично поєднати всі виміри сучасного людського буття, осмислення людиною свого «тут і тепер» як часу-простору напруженого пошуку, вибору і відповідальності.

\section{1 Бібліографія}

[1] Бауман 3. Глобализация. Последствия для человека и обществаПер. с англ. - М.: Весь Мир, 2004.

[2] Бергсон A. Творческая эволюция / Пер. с франц.-М.: КАНОНпресс, Кучково поле, 1998.

[3] Блауберг И.И. Анри Бергсон и философия длительности //Бергсон А. Собрание сочинений в четырёх томах.-М.: Московский клуб, 1992. - Том 1. 
[4] Бродель Ф. История и общественные науки. Историческая длительность // Философия и методология истории. - М.: Прогресс, 1977.

[5] Любинская Л.Н., Лепилин С.В. Проблема времени в контексте междисциплинарных исследований. - М.: Прогресс-Традиция, 2002.

[6] Князева E.Н., Курдюмов С.П. Путь самоорганизации природы: детерминация из будущего // Информация и самоорганизация. - М.: Издательство РАГС, 1996. - С. 14-33.

[7] Гайденко П.П. Проблема времени в философии жизни // Антропология культуры. - Вып. 1. - М.: ОГИ, 2002.-С.151-180.

[8] Валлерстайн И. Изобретение реальностей времени-пространства: к пониманию наших исторических систем / Время мира. Альманах. Вып.2: Структуры истории. - Новосибирск: Сибирский хронограф, 2001.

[9] Геннеп A. ван. Обряды перехода: Системное изучение обрядов. - М.: Вост. лит., 2002.

[10] Тиллих П. Систематическая теология.-М.-СПб.: Университетская книга, 2000. - Т.3.

[11] Тульчинский Г.Л. Постчеловеческая персонология. Новые перспективы свободы и рациональности. - СПб.: Алетейя, 2002.

[12] Устойчивость и неустойчивость целостных структур как предмет системного исследования. - Выпуск 1.-РАН. Институт системного анализа. - М., 1994.

[13] Хайдеггер М. Бытие и время: Пер. с нем. - M.: Ad Marginem, 1997.

[14] Bloor D. Wittgenstein: A Social Theory of Knowledge. - N.Y., 1983.

[15] Derrida J. De grammatologie. - Paris: Les Edition de Minuit, 1967.

[16] Turner V.W. The Ritual Process: Structure and Anti-Structure.Harmondsworth, 1974. 